\title{
Sex Determination in Egyptian Population from Scapula by Computed Tomography
}

\author{
Doaa A EI Morsi ${ }^{1 *}$, Ghada Gaballah², Walaa Mahmoud ${ }^{2}$ and Ahmed Ibrahiem Tawfik ${ }^{2}$
}

${ }^{1}$ Departments of Forensic Medicine and Clinical Toxicology, Mansoura University, Egypt

${ }^{2}$ Department of Diagnostic Radiology, Mansoura University, Egypt

\begin{abstract}
Sex determination is important for individual identification. The present work aims to concentrate on the accuracy of scapula for sex determination in Egyptians by using 3D multi - slice computed tomography (CT) and to generate specific population discriminant formula for Egyptians with validation of its accuracy. A descriptive comparative study is done on 100 subjects recruited from those attending the Radiology Department and subjected to CT after taken informed consent. Seven dimensions are taken for each subject from each scapula. The results reveal males have larger scapula than females with no statistical significant difference between both sides in either sex. The accuracy of both bones for sex determination reaches $88 \%$ with the scapular breadth has the highest accuracy $82 \%$. It could be concluded that scapula is useful in sex determination and the right scapula could be used alone or in combination with the left one. The discriminant equation developed from right maximum scapular height and left length of spine could apply on Egyptian population. Also CT is a good and reliable tool for scapular measurements.
\end{abstract}

Keywords: Forensic anthropology; Forensic science; Scapula; Population data; Sex determination; CT

\section{Introduction}

In forensic field, sexing of the remaining parts is fundamental; as it helps in identification and narrows the possible matches. A significant step for accurate sex determination is the estimation of dimorphic measurements in unknown cadaver [1]. In cases of intersex; sex differentiation is a complicated issue. Also with the increasing number of mass disaster, it is common to find parts of the body that need to be identified [2]. The skull and pelvis bones are the most common and valuable for sex determination and have the highest accuracy [3].

However, the scapula which is a flat short bone; has not been given the same importance as other long bones [4]. Throughout life the scapular changes are not significant after development is finished [5,6], depending on these assumptions, researches already inspected the sexual diversity of the scapula in different populations [7]. With expanding interest for accurate sex determination; it is important to enhance variable estimation methods [8]. In Egypt, different bones were used for sex determinations $[9,10]$.

Previous studies were done on determination of sex from scapula in different populations using either skeletal remains $[1,3,10-15]$, digital photographs $[5,16]$ or multi - slice computed tomography (CT) $[2,4,7,17,18]$ on different age groups and using different measurements. To the best of our insight, this Egyptian study is an interesting one which uses both scapulae in the determination of sex in Egyptians with different dimensions and different age group.

The present work aimed to concentrate on the accuracy of scapula for sex determination in Egyptians by using three dimensions (D) $\mathrm{CT}$ and to generate specific population discriminant formula for sex determination and sufficiently validate its accuracy.

\section{Subjects and Methods}

\section{Subjects}

A descriptive comparative study was conducted on a total of 100 subjects divided into 50 adult males and 50 adult females, from 25 years and above. Subjects were randomly chosen from those coming to the Radiology Department in Mansoura University Hospital of known birth date and sex. Chest CTs were for different medical purposes. Exclusion criteria were: patients aged below 25 years, any scapular fractures, bone tumors or arthritis, pathological lesions, metabolic bone diseases, connective tissue diseases and previous orthopedic surgery to ensure normal bone evaluation. A high resolution multi-slice CT was done to every subject after taken written informed consent. Protocol of the study was approved by Ethical Committee of Faculty of Medicine, Mansoura University.

\section{Methods}

Examination was performed by using 128 multi-slice CT scanner (Philips Healthcare, Best, Netherlands). With the upper limbs held up beside the head with inspiratory breath-hold, imaging was done between the upper borders of the clavicles and the kidneys. Computed tomography scan was performed with the following securing parameters: $200 \mathrm{mAs}, 120 \mathrm{kVp}, 512 \times 512$ matrix, 1.172 pitch, $64 \times 0.625 \mathrm{~mm}$ section collimation, $2 \mathrm{~mm}$ slice thickness, $1 \mathrm{~mm}$ reconstruction increment. All images were transferred to the workstation (Extended Brilliance Workspace V3.5.0.2254) for post processing. Images were recreated with a slice thickness of $1 \mathrm{~mm}$ in axial and sagittal planes. Three radiologists interpreted the images independently, each scoring 20 case images per each set. To avoid intra or inter-observer error all variables were repeated twice at the middle and end of study.

*Corresponding author: Doaa A El Morsi, Departmet of Forensic Medicine and Clinical Toxicology, Mansoura University, Egypt, Tel: 00201223872287; E-mail: dr.doaa2014@outlook.com

Received March 08, 2017; Accepted April 07, 2017; Published April 11, 2017

Citation: El Morsi DA, Gaballah G, Mahmoud W, Tawfik Al (2017) Sex Determination in Egyptian Population from Scapula by Computed Tomography. J Forensic Res 8: 376. doi: 10.4172/2157-7145.1000376

Copyright: (C) 2017 El Morsi DA, et al. This is an open-access article distributed under the terms of the Creative Commons Attribution License, which permits unrestricted use, distribution, and reproduction in any medium, provided the original author and source are credited. 
Citation: El Morsi DA, Gaballah G, Mahmoud W, Tawfik Al (2017) Sex Determination in Egyptian Population from Scapula by Computed Tomography. J Forensic Res 8: 376. doi: 10.4172/2157-7145.1000376

\section{Measurements}

After finishing the imaging, each radiologist analysed the CT images for seven parameters from each scapula (Figure 1)

- Maximum scapular height: The length between the highest point of the superior angle and the lowest point of the inferior angle;

- Scapular breadth: From the middle of the dorsal border of the glenoid fossa to the end of the spinal axis on the vertebral border;

- Maximum length of the spine: From the medial border of the scapula at the spinous axis to the most lateral point on the scapular spine;

- Glenoid cavity height: Maximum length from the upper margin of the glenoid prominence to the lower margin of the glenoid prominence - making sure that either the supra-glenoid tubercle or the infra-glenoid tubercle was included;

- Glenoid cavity breadth: Maximum length across glenoid cavity measured at a right angle to the axis of glenoid cavity height;

- Maximum acromion height: Length between the most superior and the most inferior point of the acromion process -the axis of this dimension varies from individual to individual.

- Length of infraspinous line: From the end of the spinal axis on the vertebral margin to the tip of the posterior angle.

\section{Statistical Analysis}

Data was analyzed by using SPSS (SPSS, Inc., Chicago, IL) program statistical package version 20. KolmogoroveSmirnov test was done to test the normal distribution of data. Quantitative variables were described as mean \pm standard deviation; minimum and maximum for parametric data. The statistical difference was done to compare two groups of parametric data by student - t-test. Receiver Operating Characteristics (ROC) curve for detection of scapular measurements validity in differentiation between males and females was used. Binary logistic regression was done to predict male group if equation $>$ zero. Statistical significance was considered at $\mathrm{p}$ value $<0.05$ at confidence interval 95\%. Kappa measure of agreement was used to assess the Intra - observer reliability.

\section{Results}

Inter and intra - observer error found to be small and not statistically significant ( 0.85 and 0.75 respectively). Table 1 shows the descriptive data of the studied subjects. The mean age in females was $46.08 \pm$ 12.21 and $45.76 \pm 11.09$ in males. There was no significant difference between subjects regarding age. All variables were significantly larger in males than females in both right and left sides (Table 2). By comparing the measurements in right and left side in both sexes; there was no significant difference between both scapulae in either males or females regarding any measurement (Table 3 ). The multivariate logistic regression analysis (Table 4 ); helps in sex $(\mathrm{z})$ determination by using the following equations; where $\mathrm{z}>0$ the subject is male; otherwise is female.

For right scapula: $\mathrm{z}=$ constant $(37.238)+\mathrm{B}(2.501) \times$ Right maximum scapular height.

For combined bones: $\mathrm{z}=$ Constant $(51.701)+\mathrm{B}(1.846) \times$ Right maximum scapular height $+1.844 \times$ Left length of spine.

Utilizing the most predictable measurements of both scapulae, the correct classification of both males and females (44/50) reaches $88 \%$ (Table 5). Table 6 showed that the right maximum scapular height and scapular breadth had the highest accuracy (82\%) while for left scapula;
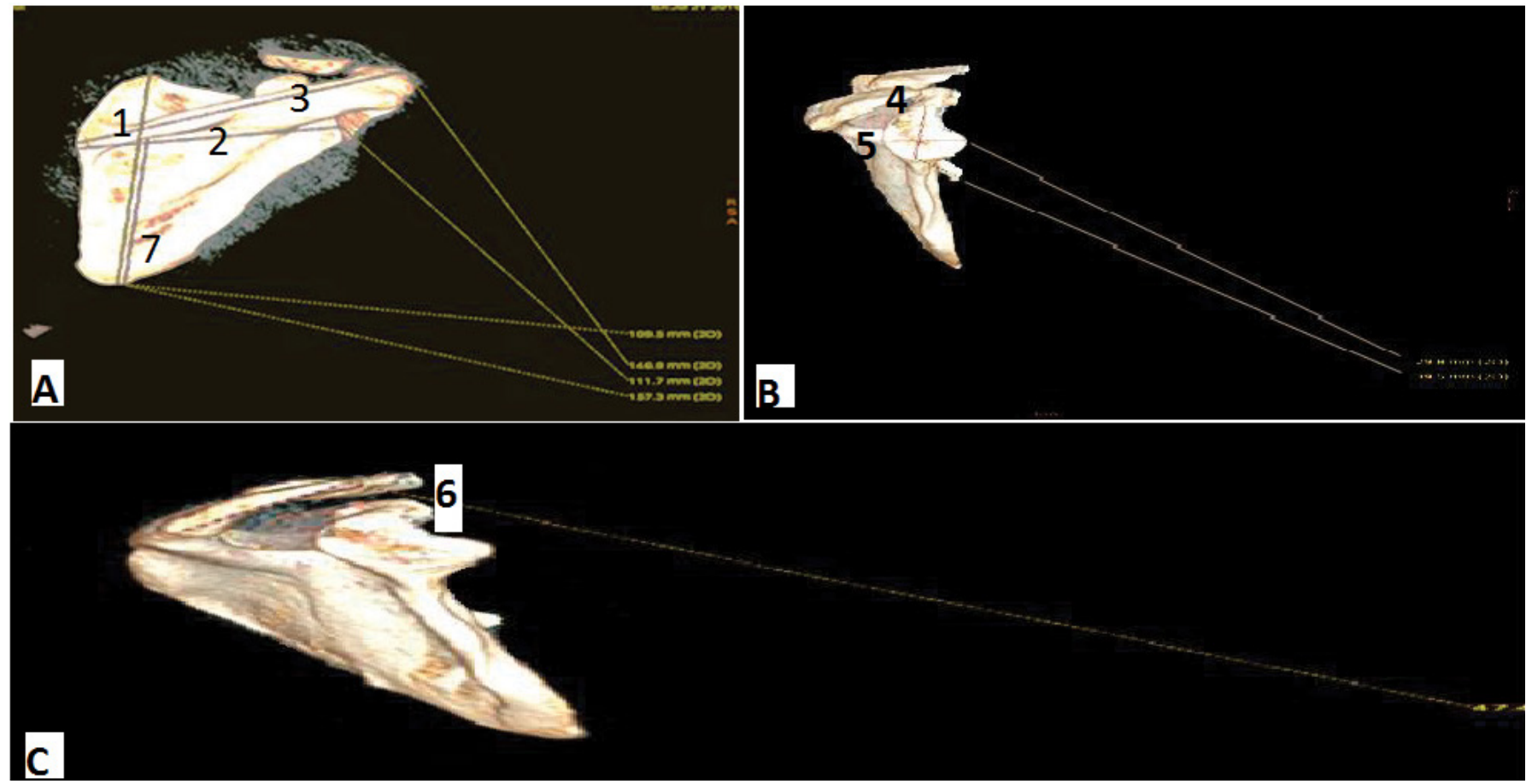

Figure 1: 3D CT scan imaging showing: a) 1. Maximum scapular height; 2 . Scapular breadth; 3 . Maximum length of spine; and 7 . Length of infraspinous line. b) 4 . Glenoid cavity height and 5. Glenoid cavity breadth. c) 6 . Maximum acromion height. 


\begin{tabular}{|c|c|c|c|c|}
\hline Sex & Min & Max & Mean \pm SD & Student $\mathrm{t}$ - test \\
\hline Males $(n=50)$ & 25 & 65 & $45.76 \pm 11.09$ & \multirow{2}{*}{$\begin{array}{l}t=0.137 \\
p=0.891\end{array}$} \\
\hline Females $(n=50)$ & 27 & 75 & $46.08 \pm 12.21$ & \\
\hline
\end{tabular}

Table 1: Descriptive statistics of the studied subjects $(n=100)$ by means of age.

\begin{tabular}{|c|c|c|c|}
\hline & $\begin{array}{l}\text { Males }(n=50) \\
\text { Min. }- \text { Max. } \\
\text { Mean } \pm \text { SD }\end{array}$ & $\begin{array}{c}\text { Females }(n=50) \\
\text { Min. }- \text { Max. } \\
\text { Mean } \pm \text { SD }\end{array}$ & $\begin{array}{c}\text { Test of } \\
\text { significance }\end{array}$ \\
\hline \multicolumn{4}{|l|}{ Right Scapula } \\
\hline $\begin{array}{l}\text { Max. Scapular } \\
\text { height }\end{array}$ & $\begin{array}{c}14.00 \pm 19.60 \\
15.90 \pm 1.08\end{array}$ & $\begin{array}{c}11.60 \pm 15.70 \\
13.87 \pm 1.00\end{array}$ & $\begin{array}{c}t=9.72 \\
p=0.000^{*}\end{array}$ \\
\hline Scapular breadth & $\begin{array}{l}9.70 \pm 11.80 \\
10.70 \pm 0.51\end{array}$ & $\begin{array}{l}9.00 \pm 11.60 \\
9.78 \pm 0.59\end{array}$ & $\begin{array}{c}t=8.32 \\
p=0.000^{*}\end{array}$ \\
\hline $\begin{array}{l}\text { Max. Length of } \\
\text { spine }\end{array}$ & $\begin{array}{l}12.30 \pm 15.00 \\
13.62 \pm 0.64\end{array}$ & $\begin{array}{l}11.00 \pm 14.00 \\
12.45 \pm 0.83\end{array}$ & $\begin{array}{c}t=7.84 \\
p=0.000^{*}\end{array}$ \\
\hline $\begin{array}{l}\text { Glenoid cavity } \\
\text { height }\end{array}$ & $\begin{array}{l}3.20 \pm 4.50 \\
3.85 \pm 0.31\end{array}$ & $\begin{array}{l}3.10 \pm 4.40 \\
3.43 \pm 0.30\end{array}$ & $\begin{array}{c}t=6.97 \\
p=0.000^{*}\end{array}$ \\
\hline $\begin{array}{l}\text { Glenoid cavity } \\
\text { breadth }\end{array}$ & $\begin{array}{l}2.10 \pm 3.30 \\
2.91 \pm 0.29\end{array}$ & $\begin{array}{l}2.10 \pm 3.00 \\
2.56 \pm 0.22\end{array}$ & $\begin{array}{c}t=6.62 \\
p=0.000^{*}\end{array}$ \\
\hline $\begin{array}{l}\text { Max. Acromion } \\
\text { height }\end{array}$ & $\begin{array}{l}3.40 \pm 5.20 \\
4.16 \pm 0.47\end{array}$ & $\begin{array}{l}3.00 \pm 5.10 \\
3.72 \pm 0.44\end{array}$ & $\begin{array}{c}t=4.83 \\
p=0.000^{*}\end{array}$ \\
\hline $\begin{array}{c}\text { Length of } \\
\text { infraspinous line }\end{array}$ & $\begin{array}{l}9.40 \pm 13.70 \\
11.48 \pm 1.06\end{array}$ & $\begin{array}{l}7.80 \pm 11.60 \\
10.24 \pm 0.91\end{array}$ & $\begin{array}{l}t=6.26 \\
p=0.00^{*}\end{array}$ \\
\hline \multicolumn{4}{|l|}{ Left Scapula } \\
\hline $\begin{array}{l}\text { Max. Scapular } \\
\text { height }\end{array}$ & $\begin{array}{c}13.70 \pm 18.40 \\
15.79 \pm 1.03\end{array}$ & $\begin{array}{c}12.00 \pm 15.50 \\
13.94 \pm 0.93\end{array}$ & $\begin{array}{c}t=9.42 \\
p=0.000^{*}\end{array}$ \\
\hline Scapular breadth & $\begin{array}{l}10.00 \pm 11.60 \\
10.73 \pm 0.49\end{array}$ & $\begin{array}{l}9.00 \pm 11.30 \\
9.83 \pm 0.61\end{array}$ & $\begin{array}{c}t=8.05 \\
p=0.000^{*}\end{array}$ \\
\hline $\begin{array}{l}\text { Max. Length of } \\
\text { spine }\end{array}$ & $\begin{array}{c}12.30 \pm 15.20 \\
13.53 \pm 0.65\end{array}$ & $\begin{array}{l}10.90 \pm 13.70 \\
12.36 \pm 0.77\end{array}$ & $\begin{array}{c}t=8.19 \\
p=0.000^{*}\end{array}$ \\
\hline $\begin{array}{c}\text { Glenoid cavity } \\
\text { height }\end{array}$ & $\begin{array}{l}3.30 \pm 4.30 \\
3.87 \pm 0.28\end{array}$ & $\begin{array}{l}3.10 \pm 4.20 \\
3.50 \pm 0.28\end{array}$ & $\begin{array}{c}t=6.76 \\
p=0.000^{*}\end{array}$ \\
\hline $\begin{array}{l}\text { Glenoid cavity } \\
\text { breadth }\end{array}$ & $\begin{array}{l}2.20 \pm 3.50 \\
2.97 \pm 0.32\end{array}$ & $\begin{array}{l}2.20 \pm 3.20 \\
2.61 \pm 0.31\end{array}$ & $\begin{array}{c}t=5.61 \\
p=0.000^{*}\end{array}$ \\
\hline $\begin{array}{l}\text { Max. Acromion } \\
\text { height }\end{array}$ & $\begin{array}{l}2.80 \pm 4.70 \\
4.05 \pm 0.49\end{array}$ & $\begin{array}{l}3.10 \pm 5.20 \\
3.66 \pm 0.42\end{array}$ & $\begin{array}{c}t=4.28 \\
p=0.000^{*}\end{array}$ \\
\hline $\begin{array}{c}\text { Length of } \\
\text { infraspinous line }\end{array}$ & $\begin{array}{l}9.00 \pm 13.80 \\
11.48 \pm 1.01\end{array}$ & $\begin{array}{l}8.30 \pm 11.60 \\
10.38 \pm 0.86\end{array}$ & $\begin{array}{c}t=5.86 \\
p=0.000^{*}\end{array}$ \\
\hline \multicolumn{4}{|c|}{$\begin{array}{l}\mathrm{n}=\text { =number; } \quad \text { Min=minimum; } \\
\mathrm{cm}=\text { centimeter; " } \text { "significant. }\end{array}$} \\
\hline
\end{tabular}

Table 2: Descriptive statistics and comparison for all measurements of the right and the left scapulae (in $\mathrm{cm}$ ) in both sexes $(n=100)$.

\begin{tabular}{|l|c|c|c|}
\hline Measurements & Sex & $\mathbf{t}$ & $\mathbf{p}$ \\
\hline Max. Scapular height & Males & 0.51 & 0.611 \\
\hline \multirow{2}{*}{ Scapular breadth } & Females & 0.372 & 0.711 \\
\hline \multirow{2}{*}{ Max. Length of spine } & Males & 1.436 & 0.154 \\
\cline { 2 - 4 } & Females & 0.398 & 0.692 \\
\hline Glenoid cavity height & Males & 0.655 & 0.514 \\
\hline \multirow{2}{*}{ Glenoid cavity breadth } & Females & 0.57 & 0.57 \\
\hline \multirow{2}{*}{ Max. Acromion height } & Males & 0.409 & 0.684 \\
\cline { 2 - 4 } & Females & 1.246 & 0.216 \\
\hline \multirow{2}{*}{ Length of infraspinous line } & Males & 0.9 & 0.37 \\
\cline { 2 - 4 } & Females & 0.89 & 0.376 \\
\hline & Males & 1.085 & 0.281 \\
\hline & Females & 0.649 & 0.518 \\
\hline
\end{tabular}

Table 3: Comparison between the right and the left scapular variables in both sexes by using student t-test.

the scapular breadth (80\%) followed by maximum scapular height and maximum length of spine (78\% each) had the higher accuracy.

\section{Discussion}

Sex determination by using different features is a contineous

\begin{tabular}{|l|l|c|c|c|c|c|}
\hline \multicolumn{2}{|c|}{ Measurements } & B & Sig. & Exp (B) & \multicolumn{2}{|c|}{$\begin{array}{c}\text { C Cl for Exp } \\
\text { (B) }\end{array}$} \\
\cline { 3 - 7 } & & & & Lower & Upper \\
\hline Step 1 & Rt Max. Scapular height & 2.501 & 0 & 12.194 & 4.535 & 32.792 \\
\cline { 2 - 7 } & Constant & 37.238 & 0 & 0 & & \\
\hline \multirow{3}{*}{ Step 2 } & Rt Max. Scapular height & 1.846 & 0 & 6.332 & 2.373 & 16.896 \\
\cline { 2 - 7 } & Lf length of spine & 1.844 & 0.007 & 6.322 & 1.656 & 24.134 \\
\hline & Constant & 51.701 & 0 & 0 & & \\
\hline
\end{tabular}

Rt=right; Lf=left; Max=maximum; Sig.=significance; Exp=exponential; $\mathrm{Cl}=$ confidence interval

Table 4: Multivariate logistic regression analysis with the use of most predictable measurements of both scapulae.

\begin{tabular}{|c|c|c|c|c|c|}
\hline \multirow{2}{*}{ Sex } & Original & \multicolumn{2}{|c|}{ Predicted group } & \multicolumn{2}{|c|}{ Accuracy \% } \\
\cline { 2 - 6 } & & Males & Females & Correct \% & Incorrect \% \\
\hline Males & 50 & 44 & 6 & $88 \%$ & $12 \%$ \\
\hline Females & 50 & 6 & 44 & $88 \%$ & $12 \%$ \\
\hline
\end{tabular}

Table 5: The correct classification of sex by using the multivariate logistic regression of both scapulae.

attempt. The present work aims to concentrate on the accuracy of scapula for sex determination in Egyptians by using 3D multi - slice computed tomography (CT) and to generate specific population discriminant formula for sex determination and sufficiently validate its accuracy.

The present results state that males have bigger scapulae than females with statistical significance $(\mathrm{p}<0.000)$ indicating sexual dimorphism of scapula; while there is no significant differences regarding the seven variables between both sapulae; meaning that the scapula is bilaterally symmetrical. Sexual dimorphism may be related to muscular activity and development in males than females.

This is in agreement with Giurazza et al. [2] in Caucasian population; Torimitsu et al. [4] in Japanese population; Zhang et al. [17] in Chinese population; and Paulis and Abu Samra [7] in Egyptian population.

Despite the agreement between the previous Egyptian study and the current one, they differ in using seven variables from both scapulae comparing to only two variables in the previous study and different age groups ( 21 years to 83 years) in the previous work compared to 25 years to 75 years in the present work.

Furthermore, the current results of the stepwise analysis of all measurements concluded a sex classification accuracy of $88 \%$ for both males and females. In addition, the right scapular breadth and maximum scapular height have the highest accuracy (82\%) followed by glenoid cavity height and breadth (76\% each); while in the left side the scapular breadth has the highest accuracy (82\%) followed by the maximum scapular height and length of the spine (78\% each).

This is in accord with Giurazza et al. [2]; Zhang et al. [17]; Paulis and AbuSamra [7]; who mentioned that transverse length or morphological breadth had the highest accuracy. On contrary, Torimitsu et al. [4] in Japan and Papaioannou et al. [1] in Greek population stated that the maximum scapular height had the highest accuracy.

The discrepancies between the current work and previous studies could be due to structural differences of scapula between different populations as a result of the growth hormone which is affected by genes and environmental factors [19]. Also, due to different methods used for measurements, as Papaioannou et al. [1] applied the measurements directly from the bone while in the present work the measurements were taken from CT. 
Citation: El Morsi DA, Gaballah G, Mahmoud W, Tawfik Al (2017) Sex Determination in Egyptian Population from Scapula by Computed Tomography. J Forensic Res 8: 376. doi: 10.4172/2157-7145.1000376

Page 4 of 4

\begin{tabular}{|c|c|c|c|c|c|}
\hline Measurements & AUC & Cutoff & Sensitivity (\%) & Specificity (\%) & Accuracy (\%) \\
\hline \multicolumn{6}{|l|}{ Right Scapula } \\
\hline Max. Scapular height & 0.933 & Males $\geq 14.55>$ females & 92 & 72 & 82 \\
\hline Scapular breadth & 0.89 & Males $\geq 10.15>$ females & 88 & 76 & 82 \\
\hline Max. Length of spine & 0.857 & Males $\geq 12.95>$ females & 80 & 68 & 74 \\
\hline Glenoid cavity height & 0.848 & Males $\geq 3.55>$ females & 84 & 68 & 76 \\
\hline Glenoid cavity breadth & 0.83 & Males $\geq 2.65>$ female & 84 & 68 & 76 \\
\hline Max. Acromion height & 0.761 & Males $\geq 3.75>$ female & 76 & 56 & 66 \\
\hline Length of infraspinous line & 0.803 & Males $\geq 10.60>$ female & 80 & 64 & 72 \\
\hline \multicolumn{6}{|l|}{ Left Scapula } \\
\hline Max. Scapular height & 0.913 & Males $\geq 14.65>$ female & 84 & 72 & 78 \\
\hline Scapular breadth & 0.85 & Males $\geq 10.05>$ female & 96 & 64 & 80 \\
\hline Max. Length of spine & 0.874 & Males $\geq 12.75>$ female & 88 & 68 & 78 \\
\hline Glenoid cavity height & 0.838 & Males $\geq 3.65>$ female & 87 & 63.6 & 68 \\
\hline Glenoid cavity breadth & 0.79 & Males $\geq 2.55>$ female & 88 & 52 & 70 \\
\hline Max. Acromion height & 0.752 & Males $\geq 3.65>$ female & 72 & 56 & 68 \\
\hline Length of infraspinous line & 0.797 & Males $\geq 10.9>$ female & 72 & 60 & 66 \\
\hline
\end{tabular}

Table 6: Cut off values and accuracy for each variable in both sides $(n=100)$

By using CT to measure the different variables; CT is a good tool and the skeletal measurements based on CT could be standardized because the anatomical landmarks are easy to locate. Besides, CT images could be stored forever in small space and be retrieved at any time. Although CTs deliver high radiation doses, it is less harmful during routine cadaveric examination $[2,4,20]$.

Limitation of this study was the small sample size which could affect the accuracy of each measurement and did not reach the forensic required cut off $(85 \%)$.

\section{Conclusion}

It could be concluded that scapula is useful bone for sex determination and the right scapula could be used either alone or in combination with the left one. The discriminant equation developed from right maximum scapular height and left length of spine is applicable to Egyptian population. Also CT is a good and reliable tool for scapular measurements.

\section{References}

1. Papaioannou VA, Kranioti EF, Joveneaux $P$, Nathena $D$, Michalodimitrakis $M$ (2012) "Sexual dimorphism of the scapula and the clavicle in a contemporary Greekpopulation: Applications in forensic identification”. Forensic Sci Int 217: 231e1-231e7.

2. Giurazza F, Schena E, Del Vescovo R, Cazzato RL, Mortato L, et al. (2013) Sex determination from scapular length measurements by CT scan images in a Caucasian population. Conf Proc IEEE Eng Med Biol Soc pp: 1632-1635.

3. Peckmann TR, Logar C, Meek S (2016) Sex estimation from the scapula in a contemporary Chilean population. Sci Justice 56: 357-363.

4. Torimitsu S, Makino Y, Saitoh H, Sakuma A, Ishii N, et al. (2016) Sex estimation based on scapula analysis in a Japanese population using multidetector computed tomography. Forensic Sci Int 262: 285e1-285e5.

5. Scholtz Y, Steyn M, Pretorius E (2010) A geometric morphometric study into the sexual dimorphism of the human scapula. Homo 61: 253-270.

6. Ross $\mathrm{AH}$, Ubelaker DH, Kimmerle EH (2011) Implications of dimorphism, population variation, and secular change in estimating population affinity in the Iberian Peninsula. Forensic Sci Int 206: 214e1-214e5.

7. Paulis MG, Abu Samra MF (2015) Estimation of sex from scapular measurements using chest CT in Egyptian population sample. Journal of Forensic Radiology and Imaging 3: 153-157.

8. Abd-elaleem SA, Abd-elhameed M, Ewis AA (2012) Talus measurements as a diagnostic tool for sexual dimorphism in Egyptian population. J Forensic Legal Med 19: 70-76.

9. Azab SM, Khalifa S (2014) Indicators for sex determination from the mandibular ramus among adult Egyptian population - a digital radiographic study, Egypt. Dent J 60: 773-779.

10. Patel SM, Shah MA, Vora RK, Rathod SP, Shah S (2013) Morphometric analysis of scapula to determine sexual dimorphism. Int J Med Public Health 3: 207-210.

11. Dabbs GR (2009) Is dwight right? Can the maximum height of the scapula be used for accurate Sex estimation? J Forensic Sci 54: 529-530.

12. Dabbs G (2010) Sex determination using the scapula in New Kingdom skeletons from Tell El-Amarna dimorphism of the human scapula. Homo 61: 413-420.

13. Dabbs GR, Moore-Jansen PH (2010) A method for estimating sex using metric analysis of the scapula. J Forensic Sci 55: 149-152.

14. Özer I, Katayama K, Sahgir M, Güleç E (2006) Sex determination using the scapula in Medieval Skeletons from East Anatolia. Coll Antropol 30: 415-419.

15. Hudson A, Peckmann TR, Logar CJ, Meek S (2016) Sex determination in a contemporary Mexican population using the scapula. J Forensic Leg Med 37: 91-96.

16. Macaluso PJ (2011) Sex discrimination from the glenoid cavity in black South Africans: Morphometric analysis of digital photographs. Int J Legal Med 125: 773-778.

17. Zhang K, Cui JH, Luo YZ, Fan F, Yang M, et al. (2016) Estimation of stature and sex from scapular measurements by three-dimensional volume-rendering technique using in Chinese. Leg Med (Tokyo) 21: 58-63.

18. Badr El Dine FMM, Hassan HHM (2016) Ontogenetic study of the scapula among some Egyptians: Forensic implications in age and sex estimation using Multidetector Computed Tomography. Egypt J Forensic Sci 6: 56-77.

19. Capellini TD, Vaccari G, Ferretti E, Fantini S, He M, et al. (2010) Scapula development is governed by genetic interactions of $\mathrm{Pbx} 1$ with its family members and with Emx2 via their cooperative control of Alx1. Development 137: 2559-2569.

20. Dedouit F, Telmon N, Costagliola R, Otal P, Joffre F et al. (2007) Virtua anthropology and forensic identification: report of one case. Forensic Sci Int 173:182-187. 